\title{
CAMPUR KODE DI LINGKUNGAN MASYARAKAT PANCOR SANGGENG, KABUPATEN LOMBOK TIMUR
}

\author{
Dian Aprila Diniarti ${ }^{1}$; Haeruddin ${ }^{2}$ \\ ${ }^{1,2}$ SMA Negeri 2 Mataram
}

\begin{abstract}
ABSTRAK
Permasalahan yang hendak dikaji dalam penelitian ini adalah bentuk dan faktor penyebab terjadinya campur kode pada masyarakat Pancor Sanggeng di Lombok Timur. Masyarakat Pancor Sanggeng adalah masyarakat yang bilingual karena menguasai dua bahasa yaitu bahasa Indonesia dan bahasa daerah. Penguasaan terhadap dua bahasa tersebut memungkinkan terjadinya campur kode dalam setiap tuturan masyarakat tersebut karena penggunaan bahasa Indonesia lebih dominan dibandingkan bahasa daerah. Berdasarkan permasalahan tersebut, tujuan dalam penelitian ini adalah mendeskripsikan bentuk campur kode dan faktor penyebab terjadinya campur kode pada tuturan masyarakat Pancor sanggeng. Jenis penelitian ini adalah deskriptif kualitatif. Pengumpulan data dilakukan melalui metode observasi dan sadap suara. Berdasarkan analisis data yang telah dilakukan, hasil penelitian yang ditemukan berupa bentuk campur kode dalam tuturan masyarakat Pancor sanggeng adalah campur kode dalam bentuk kata dan frasa. Sedangkan faktor penyebab terjadinya campur kode ada tiga yaitu, (1) persamaan latar belakang bahasa pertama (B1), (2) merupakan wilayah kota sehingga memungkinkan mereka untuk menggunakan bahasa Indonesia lebih sering daripada bahasa ibu, dan (3) faktor gengsi yang tinggi untuk menunjukkan identitas mereka yang tinggal di kota.
\end{abstract}

\section{Kata kunci: Campur Kode}

\section{Pendahuluan}

Bahasa merupakan alat komunikasi yang tidak bisa terlepas dari kehidupan sosial masyarakat. Dalam kehidupan sosial, kita mengetahui adanya masyarakat yang terbuka, artinya para anggota masyarakat tersebut dapat menerima kedatangan anggota masyarakat lain. Bahasa dari masyarakat yang menerima kedatangan akan saling mempengaruhi dengan bahasa dari masyarakat yang datang. Dari peristiwa penerimaan tersebut, maka akan terjadi apa yang disebut kontak bahasa. Hal yang paling menonjol dari adanya kontak bahasa antara masyarakat yang satu dengan masyarakat yang lain adalah terjadinya bilingualisme dan multilingualisme. Terjadinya kontak bahasa akan mempengaruhi bahasa yang berkontak, dan pengaruh kontak bahasa tersebut adalah terjadinya alih kode dan campur kode.

Pembicaraan mengenai alih kode, biasanya diikuti dengan pembicaraan tentang campur kode. Campur kode terjadi apabila seorang penutur bahasa, misalnya bahasa Indonesia memasukkan unsur-unsur bahasa daerahnya ke dalam pembicaraan bahasa Indonesia. Dengan kata lain, seseorang yang berbicara dengan kode utama bahasa Indonesia yang memiliki fungsi keotonomiannya, sedangkan kode bahasa daerah yang terlibat dalam kode utama merupakan serpihan-serpihan saja tanpa fungsi atau keotonomian sebagai sebuah kode. Campur kode hanyaakan terjadi pada masyarakat yang bilingual.

Penutur bilingual maksudnya adalah orang yang mampu atau bisa menggunakan dua bahasa, dan lazimnya dalam bahasa Indonesia disebut dwibahasawan. Sedangkan kemampuan menggunakan dua bahasa disebut bilingualisme yang dalam bahasa Indonesia disebut kedwibahasaan. Bloomfield (dalam Chaer dan Agustina, 2010: 85), “mengatakan bahwa bilingualisme adalah kemampuan seorang penutur untuk menggunakan dua bahasa dengan sama baiknya". Pengertian di atas dapat kita simpulkan bahwa seseorang dikatakan bilingual apabila seseorang tersebut menguasai B1 dan B2 sama baiknya. 
Sejalan dengan itu, banyak para ahli yang membenahi pendapat dari Bloomfield tentang bilingualisme. Haugen (dalam Chaer dan Agustina (2010: 86), "mengatakan seorang bilingual tidak perlu secara aktif menggunakan kedua bahasa itu, tetapi cukup kalau bisa memahaminya saja". Dari pendapat yang dikemukakan Haugen dapat kita simpulkan bahwa seseorang dikatakan bilingual tidak mesti menguasi dengan baik B2 nya, dengan tahu sedikit saja sudah dikatakan bilingual. Baik sedikit maupun banyak menguasai B2, semua itu memiliki peluang besar terhadap terjadinya campur kode dalam setiap tuturan yang dilakukan penutur suatu bahasa.

Ketika penutur atau masyarakat tutur menguasai B1 dan B2 sama baiknya, maka terdapat peluang besar dalam masyarakat tutur tersebut untuk melakukan campur kode dalam setiap tuturannya. Hal itu terjadi pada masyarakat di desa Pancor kecamatan Selong Lombok Timur. Sebagian besar masyarakat Pancor sangat aktif menggunakan bahasa Indonesia sebagai bahasa keseharian mereka. Meskipun masyarakat Pancor menggunakan bahasa Indonesia sebagai bahasa keseharian mereka berkomunikasi dengan anggota keluarga, tetangga dan masyarakat lain yang ada di sekitarnya, namun dalam setiap tuturannya masih terdapat serpihan-serpihan B1 dalam bentuk kata maupun frasa. Oleh karena itu, yang akan dibahas dalam penelitian ini adalah campur kode yang dilakukan oleh masyarakat tutur yang ada di lingkungan perumahan desa Pancor Sanggeng untuk melihat bentuk campur kode yang dilakukan.

Pada umumnya campur kode dalam peristiwa komunikasi di lingkungan masyarakat yang menguasai B1 dan B2 sama baiknya,dapat dilihat dari tiga bentuk,yaitu bentuk kata, frasa,dan kalusa. Berdasarkan hal tersebut, maka permasalahan dalam penelitian ini adalah sebagai berikut:

1. Bagaimanakah bentuk campur kode yang dilakukan masyarakat tutur yang ada di desa Pancor Sanggeng?

2. Faktor apa saja yang penyebab campur kode dalam peristiwa komunikasi di lingkungan desa Pancor Sanggeng?
Berdasarkan rumusan masalah yang di atas, maka tujuan dalam penelitian ini adalah sebagai berikut:

1. Mendeskripsikan bentuk campur kode yang dilakukan oleh masyarakat tutur yang ada di desa Pancor Sanggeng.

Mendeskripsikan faktor-faktor penyebab terjadinya campur kode dalam peristiwa komunikasi dilingkungan desa Pancor Sanggeng.

\section{Kajian Teoritis}

Sosiolinguistik merupakan ilmu antardisiplin antara sosiologi dan linguistik. Kedua bidang ilmu empiris ini mempunyai kaitan yang sangat erat. Untuk memahami apa itu sosiolinguistik, perlu diketahui apa itu sosiologi dan linguistik. Sosiologi merupakan ilmu yang mempelajari hubungan antar manusia di dalam masyarakat. Secara konkret, sosiologi mempelajari kelompok-kelompok dalam masyarakat, seperti keluarga, clan (subsuku), suku, bangsa (Sumarsono, 2011: 5). Sedangkan linguistik adalah bidang ilmu yang mempelajari bahasa, atau bidang ilmu yang mengambil bahasa sebagai objek kajiannya (Chaer dan Agustina, 2010: 2).

Appel (dalam Aslinda dan Leni, 2010: 6) mengatakan, sosiolinguistik memandang bahasa sebagai sistem social dan sistem komunikasi serta merupakan bagian dari masyarakat dan kebudayaan tertentu. Sedangkan Fishman (dalam Chaer dan Agustina, 2010: 3) mengatakan sosiolinguistik adalah kajian tentang ciri khas variasi bahasa, fungsi-fungsi variasi bahasa, dan pemakai bahasa karena ketiga unsur ini selalu berinteraksi, berubah, dan saling mengubah satu sama lain dalam satu masyarakat tutur. Dengan demikian, maka dapat dikatakan bahwa sosiolinguistik adalah bidang ilmu antardisiplin yang mempelajari bahasa dalam kaitannya dengan penggunaan bahasa di masyarakat.

\section{Kontak Bahasa}

Seperti yang sudah dijelaskan sebelumnya, bahwa masyarakat yang dapat menerima kedatangan masyarakat lain , baik satu atau lebih dari satu masyarakat, akan terjadilah apa yang disebut kontak bahasa. "Bahasa dari 
masyarakat yang menerima akan saling mempengaruhi dengan bahasa dari masyarakat yang datang" (Chaer, 2012: 65). Terjadinya kontak bahasa tersebut melahirkan adanya bilingualisme dan multilingualisme dengan berbagai kasusnya, yaitu interferensi, integrasi, alih kode, dan campur kode.

\section{Bilingualisme}

Istilah bilingualisme dalam bahasa Indonesia disebut juga kedwibahasaan. Bilingualisme adalah penggunaan dua bahasa atau dua kode bahasa. Secara sosiolinguistik, bilingualisme diartikan sebagai penggunaan dua bahasa oleh seorang penutur dalam pergaulannyadengan orang lain secara bergantian (Mackey 1962, Fishman 1975 dalam Chaer dan Agustina, 2010: 84). Untuk menggunakan dua bahasa, tentunya seseorang harus menguasai kedua bahasa itu,yaitu bahasa pertama (B1) dan bahasa kedua (B2). Orang yang dapat menggunakan kedua bahasa itu disebut dengan orang yang bilingual. Sedangkan kemampuan untuk menggunakan dua bahasa disebut bilingualitas.

Pendapat lain dikemukakan oleh Blommfield (dalam Aslinda dan Leni, 2010: 23) mengenai bilingualisme atau disebut juga dengan kedwibahasaan adalah penguasaan yang sama baiknya terhadap dua bahasa. Menurutnya, mengenal dua bahasa berarti mampu menggunakan dua sistem kode secara baik.

\section{Peristiwa Tutur}

Dalam setiap komunikasi interaksi linguistik, manusia saling menyampaikan informasi, baik berupa gagasan, maksud, pikiran, perasaan,maupun emosi secara langsung. Hubungannya dengan peristiwa tutur adalah berlangsungnya atau terjadinya interaksi linguistik dalam suatu ujaran atau lebih yang melibatkan dua pihak atau lebih, yakni penutur dan mitra tutur dengan satu pokok tuturan dalam waktu,tempat dan situasi tertentu (Chaer dan Agustina, 2010:47).

Berdasarkan pengertian peristiwa tutur tersebut, secara konkret kita dapat menentukan interaksi yang disebut sebagai peristiwa tutur linguistik, antara lain rapat di kantor, diskusi dalam ruang perkuliahan, siding di pengadilan, interaksi antar pedagang dan pembeli di pasar, dan perckapan di lingkungan tempat tinggal. Menurut sosiolinguis terkenal yaitu Hymes (dalam Aslinda dan Leni, 2010: 32), bahwa suatu peristiwa tutur harus memenuhi delpan komponen tutur yang diakronimkan menjadi SPEAKING. Kedelapan komponen tersebut adalah setting and scene, participant, ends, act sequences, key, instrumentalities, norm of interaction and interpretation, dan genre.

\section{Campur Kode}

Campur kode biasanya terjadi apabila seorang penutur bahasa memasukkan unsur-unsur bahasa pertamanya ke dalam bahasa keduanya ketika melakukan proses komunikasi. Alih kode dan campur kode adalah gejala bahasa yang sulit untuk dibedakan. Kesamaan yang ad antara alih kode dan campur kode yaitu digunakannya dua bahasa atau lebih, atau dua varian dari sebuah bahasa dalam satumasyarakat tutur (Chaer dan Agustina, 2010: 114).

Seorang penutur misalnya, dalam melakukan komunikasi berbahasa Indonesia banyak menyelipkan serpihan-serpihan bahasa daerahnya, bisa dikatakan telah melakukan campur kode. Akibatnya, akan muncul satu ragam bahasa Indonesia yang kesasak-sasakan (kalau bahasa daerahnya adalah bahasa Sasak). Thelander (dalam Aslinda dan Leni, 2010: 87) mencoba menjelaskan perbedaan antara alih kode dan campur kode. Menurutnya, bila dalam peristiwa tutur terjadi peralihan dari satu klausa suatu bahasa ke klausa bahasa lain, maka peristiwa yang terjadi adalah alih kode. Akan tetapi, jika dalam suatu peristiwa tutur klausa-klausa dan frase-frase yang digunakan terdiri dari klausa dan frase campuran dan masing-masing klausa dan frase itu tidak lagi mendukung fungsi sendirisendiri, maka peristiwa yang terjadi adalah campur kode.

\section{Jenis dan Bentuk Campur Kode}

Ada dua jenis campur kode yaitu, campur kode sementara dan campur kode permanen. Campur kode sementara terjadi apabila pemakai 
bahasa mensitir kalimat B2 ketika sedang menggunakan B1, atau sebaliknya. Sedangnkan campur kode permanen terjadi karena perubahan relasi antara pembicara dengan mitra bicara, misalnya mitra bicara semula adalah teman akrab, tetapi mitra bicara itu sekarang menjadi atasan, biasanya pembicara akan mengganti kode bahasa yang digunakan secara permanen karena adanya perubahan status sosial dan relasi kepribadian yang ada.

Tidak terlalu salah kalau banyak orang yang berpendapat bahwa campur kode itu dapat berupa pencampuran serpihan kata, frase, dan klausa suatu bahasa didalam bahasa lain yang digunakan (Chaer dan Agustina, 2010: 117). Pendapat yang hamper sama juga dikemukakan oleh Suwito (dalam Herawati, 2016: 7) yang menyatakan ada lima wujud campur kode, yaitu:

1. Penyisipan kata

2. Penyisipan frasa

3. Penyisipan klausa

4. Penyisipan ungkapan atau idiom, dan

5. Penyisipan bentuk baster.

Semua itu bisa saja terjadi dalam setiap tuturan bahasa yang digunakan oleh penutur yang menguasai dua bahas atau lebih. Intinya, ada satu bahasa yang digunakan, tetapi di dalamnya terdapat serpihan-serpihan dari bahasa lain.

\section{Penyebab Campur Kode}

Menurut Kachru (dalam Herawati, 2016:

6) membedakan factor penyebab terjadinya campur kode menjadi dua aspek, yaitu aspek eksternal dan aspek internal. Aspek eksternal merupakan potensi kebahasaan penutur, baik dalam penguasaan kebahasaan maupun psikologi penutur yang terekspresi lewat campur kode tersebut. Sedangkan aspek internal terkait dengan potensi bahasa itu sendiri dalam keberadaannya di masyarakat.

\section{Metode Penelitian}

Jenis penelitian ini adalah deskriptif kualitatif. Jenis penelitian deskriptif kualitatif merupakan jenis penelitian yang menekankan pada observasi dan keadaan atau fenomenafenomena yang terjadi dalam masyarakat secara alamiah. Artinya, data yang dikumpulkan berasal dari lingkungan yang nyata dan apa adanya. Alwi dkk, (2013: 28) mengatakan penelitian kualitatif memiliki ciri-ciri, yaitu; memiliki sifat deskriptif analitik, tekanan pada proses bukan hasil, bersifat induktif, dan mengutamakan makna.

\section{Data dan Sumber Data}

Data dalam penelitian ini adalah data lisan hasil tuturan dalam peristiwa komunikasi yang dilakukan oleh masyarakat yang ada di Pancor Sanggeng Lombok Timur. Sedangkan sumber data dalam penelitian ini adalah masyarakat atau warga yang ada di Pancor Sanggeng.

\section{Teknik Pengumpulan Data}

Teknik pengumpulan data dalam penelitian ini adalah teknik observasi dan teknik sadap. Observasi adalah teknik pengumpulan data yang dilakukan dengan pengamatan secara langsung pada objek penelitian. Metode ini sering diartikan sebagai pengamatan dan pencatatan secara sistematik. Hal tersebut sesuai dengan pendapat Sukandarrumidi (2004:69) yang mengatakan bahwa observasi merupakan kegiatan pengamatan dan pencatatan suatu objek dengan sistematika fenomena yang diselidiki.

Teknik sadap adalah teknik pengumpulan data yang dilakukan secara sembunyi tanpa diketahui oleh pihak lain. Teknik ini digunakan untuk mendapatkan informasi yang dibutuhkan oleh peneliti untuk penelitiannya. Dalam penelitian ini, peneliti menggunakan teknik sadap, yaitu merekam secara sembunyi peristiwa percakapan antar masyarakat di Pancor Sanggeng.

\section{Teknik Analisis Data}

Teknik analisis data yang digunakan dalam penelitian ini adalah analisis data kualitatif model Miles dan Huberman. Model analisis data tersebut adalah data collection, data reduction, data display, conclusions. 


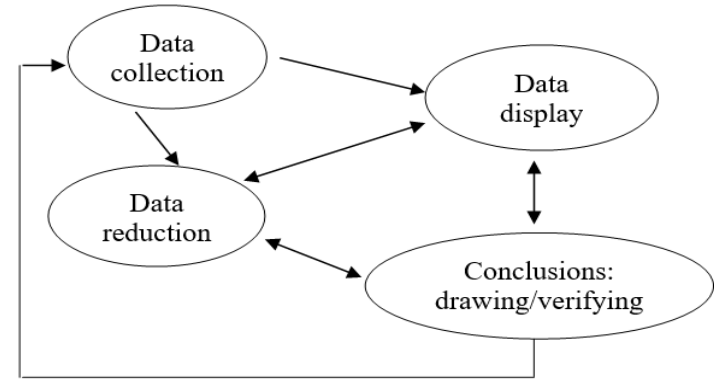

(Miles dan Huberman 1992)

Setelah melakukan penelitian, banyak sekali data yang didapat oleh peneliti. Data-data tersebut sesungguhnya masih belum valid dan banyak data yang dianggap tidak penting atau tidak termasuk ke dalam penelitian yang dilakukan oleh peneliti, sehingga perlu dilakukan reduksi data. "Mereduksi data berarti merangkum, memilih hal-hal yang pokok, dan memfokuskan hal-hal yang penting"(Sugiyono, 2010: 92). Setelah data direduksi, maka langkah selanjutnya adalah mendisplaykan data, yakni peneliti harus menyajikan data yang telah direduksi kemudian menarik kesimpulan dari hasil penelitian yang dilakukan dalam jangka waktu yang telah direncanakan sebelumnya.

\section{Pembahasan}

\section{Bentuk campur kode dalam peristiwa komunikasi di lingkungan masyarakat pancor}

Bentuk campur kode yang dilakukan di lingkungan masyarakat Pancor Sanggeng adalah campur kode berbentuk kata dan campur kode berbentuk frasa. Untuk lebih jelasnya akan diuraikan sebagai berikut.

\section{Campur Kode dalam Tataran Kata}

Konteks

: peristiwa tuturan terjadi di luar rumah seorang warga. Salah seorang anak perempuan sedang memanggil temannya.

Luluk : Devi...Devi...

Devi :Ya.....

Luluk : Lagi ngapain itu?

Devi : Saya lagi mopok nih, tunggu sebentar.
(Saya lagi nyuci nih, tunggu sebentar)

Tuturan kalimat tersebut mengalami peristiwa campur kode, yakni pada tuturan Devi ketika menjawab pertanyaan Luluk. Campur kode dalam tuturan Devi "saya lagi mopok nih, tunggu sebentar", kata "mopok" dalam bahasa Sasak masyarakat Pancor memiliki arti atau terjemahan dalam bahasa Indonesia, yaitu "nyuci". Kata "mopok" atau "nyuci" yang dikatakan Devi pada tuturannya menunjukkan pekerjaannya saat itu bahwa dia sedang mencuci pakaian ketika Luluk memanggilnya.

Konteks : Peristiwa tuturan yang terjadi di sebuah warung.

Pembeli : Jadi side belikan saya jagung?

Penjual : Astage saya lupa, maaf ya.

Tuturan kalimat tersebut mengalami peristiwa campur kode pada tuturan keduanya, yaitu pada tuturan pembeli dan penjual. Pada tuturan pembeli terjadi campur kode kata "side" pada tuturan "jadi side belikan saya jagung?" Kata "side" dalam bahasa Sasak masyarakat Pancor memiliki arti atau terjemahan dalam bahasa Indonesia yaitu "Kamu" yang merujuk langsung kepada penjual. Campur kode juga terjadi pada kata "astage" dalam tuturan penjual yang menjawab pertanyaan pembeli "astage saya lupa, maaf ya". Kata "astage" dalam bahasa Sasak masyarakat Pancor memiliki kesamaan bentuk dan arti dalam bahasa Indonesia "astaga", hanya perbedaannya pada fonem terakhir. Pada kata "astage" dalam bahasa Sasak menggunakan fonem [e] pada suku kata terakhir. Sedangkan pada kata "astaga" dalam bahasa Indonesia menggunakan fonem [a] pada suku kata terakhir. Meskipun berbeda, namun sejatinya kata "astage" bahasa Sasak dan kata "astaga" bahasa Indonesia mempunya arti dan maksud yang sama dalam setiap konteks penggunaannya jika kita mengacu pada arti dalam Kamus Besar Bahasa Indonesia (KBBI) edisi ketiga.

\section{Campur Kode dalam Tataran Frasa}

Konteks : Peristiwa tuturan yang terjadi ketika anak-anak sedang main kelereng.

Malik : Roni pengen ikut main, Dul. 
Dul

celang.

: Jangan kasih dia ikut main, ye

(Jangan kasih dia ikut main, dia

curang)

Pada peristiwa tuturan tersebut telah terjadi campur kode yang terlihat jelas pada frase "ye celang" pada tuturan Dul "jangan kasih dia ikut main, ye celang". Frase "ye celang" dalam bahasa Sasak masyarakat Pancor memiliki arti dan terjemahan dalam bahasa Indonesia, yaitu " dia curang”. Tuturan Dul tersebut memiliki makna penolakan yang sangat jelas ketika dia mengatakan "jangan kasih dia ikut main". Alasan penolakan tersebut terdapat pada frase "ye celang" atau "dia curang".

Konteks : Peristiwa tutur terjadi di halaman rumah pak Dul, ketika Rio dan Malik melihat motor VIXION yang baru dibeli pak Dul.

Malik : Rio, dendeq ntiq, nanti dimarahi pak Dul.

(Rio, jangan pegang, nanti dimarahi pak Dul)

Pada peristiwa tuturan tersebut telah terjadi campur kode yang dilakukan oleh Malik pada tuturannya "Rio, dendeq ntiq, nanti dimarahi pak Dul". Pada tuturan Malik tersebut, terjadi campur kode karena terdapat serpihan bahasa Sasak "dendeq ntiq" dalam tuturan bahasa Indonesia yang sedang digunakan oleh Malik. Pada tuturan "dendeq ntiq" dalam bahasa Sasak masyarakat Pancor memiliki terjemahan "jangan pegang" dalam bahasa Indonesia yang berarti sebuah larangan. Serpihan bahasa Sasak "dendeq ntiq" atau "jangan pegang" merupakan larangan Malik kepada Rio untuk tidak memegang motor baru milik pak Dul karena takut beliau akan marah.

\section{Faktor Penyebab Terjadinya Campur Kode Pada Masyarakat Pancor Sanggeng.}

Setelah dilakukan penelitian pada masyarakat Pancor Sanggeng, maka ditemukan beberapa faktor penyebab terjadinya campur kode pada masyarakat tersebut adalah (a) persamaan latar belakang bahasa pertama (B1), (b) merupakan wilayah kota sehingga memungkinkan mereka untuk menggunakan bahasa Indonesia lebih sering daripada bahasa ibu, dan (c) faktor gengsi yang tinggi untuk menunjukkan identitas mereka yang tinggal di kota.

\section{Penutup}

\section{Kesimpulan}

Berdasarkan data yang ada, ternyata tuturan di lingkungan masyarakat Pancor Sanggeng menunjukkan bahwa masyarakat di sana adalah masyarakat yang bilingual. Seperti yang sudah dibahas sebelumnya bahwa masyarakat yang bilingual memungkinkan terjadinya campur kode dalam setiap tuturannya. Hal tersebut benar terjadi dan terbukti pada masyarakat bilingual yang ada di lingkungan Pancor Sanggeng. Bentuk campur kode yang terjadi dalam peristiwa komunikasi masyarakat Pancor adalah campur kode berbentuk kata dan campur kode dalambentuk frasa. Sedangkan faktor penyebab terjadinya campur kode pada masyarakat tersebut adalah (a) persamaan latar belakang bahasa pertama (B1), (b) merupakan wilayah kota sehingga memungkinkan mereka untuk menggunakan bahasa Indonesia lebih sering daripada bahasa ibu, dan (c) faktor gengsi yang tinggi untuk menunjukkan identitas mereka yang tinggal di kota. Melihat dari bentuk serta penyebab campur kode pada masyarakat Pancor, dapat disimpulkan bahwa semakin sering seseorang menggunakan bahasa kedua (B2) maka semakin sedikit campur kode yang terjadi dalam setiap tuturannya.

\section{Saran}

Berdasarkan kesimpulan di atas, peneliti memberikan saran yaitu:

1. Agar ada penelitian yang sama tentang campur kode di lingkungan masyarakat yang menggunakan B2 lebih besar daripada B1, sehingga masyarakat tahu bahwa dalam berkomunikasi, terjadi campur kode pada peristiwa tutur dalam pemakaian bahasa yang sedang digunakan

2. Supaya penelitian ini bisa dijadikan sebagai landasan penelitian selanjutnya dalam bidang sosiolinguistik untuk pengajaran bahasa. 


\section{Daftar Pustaka}

Aslinda dan Leni Syafyahya. 2010. Pengantar Sosiolinguistik. Bandung: Refika Aditama.

Alwi, Mijahamuddin dkk. 2013. Penelitian Pendidikan. PGSD STKIP Hamzanwadi Selong.

Chaer, Abdul dan Leoni Agustina. 2010. Sosiolinguistik Perkenalan Awal. Jakarta: Rineka Cipta.

Herawati. 2016, "Campur Kode dalam Peristiwa Komunikasi di Lingkungan Sekolah SMA Negeri 1 Kabangka", Jurnal Humanika, 16 (1): 1-15.

Miles M. B., \& Huberman, A. M. 1992. Analisis Data Kualitatif. Jakarta: Universitas Indonesia.

Sugiyono. 2010. Memahami Penelitian Kualitatif. Bandung: Alfabeta.

Sukandarrumidi. 2004. Metodologi Penelitian. Yogyakarta: Gadjah Mada University Press.

Sumarsono. 2011. Sosiolinguistik. Yogyakarta: Pustaka Pelajar.

Poerwadarminta. 2014. Kamus Besar Bahasa Indonesia Edisi Ketiga. Jakarta: PT Balai Pustaka. 